\title{
People's Aspirations from Smart City Technologies: What Solutions They Have to Offer for the Crucial Challenges City of Jeddah Is Facing
}

\author{
Mohammed Aljoufie, Alok Tiwari \\ Department of Urban and Regional Planning, Faculty of Environmental Design, King Abdulaziz University, Jeddah, Saudi Arabia \\ Email: atwari@kau.edu.sa, alok.niea@gmail.com
}

How to cite this paper: Aljoufie, M., \& Tiwari, A. (2017). People's Aspirations from Smart City Technologies: What Solutions They Have to Offer for the Crucial Challenges City of Jeddah Is Facing. Current Urban Studies, 5, 466-482.

https://doi.org/10.4236/cus.2017.54026

Received: May 26, 2017

Accepted: December 9, 2017

Published: December 12, 2017

Copyright ( 92017 by authors and Scientific Research Publishing Inc. This work is licensed under the Creative Commons Attribution International License (CC BY 4.0).

http://creativecommons.org/licenses/by/4.0/

(c) (i) Open Access

\begin{abstract}
Saudi Arabian urban society is faced with critical challenges such as environmental degradation, unsustainable resource consumption, inadequate public transportation, lack of walkable and bike friendly urban neighbourhoods that are hampering general conditions of liveability and wellbeing. In response to these challenges, legislators planned 6 economic cities that are metonym of smart cities, intended to economic diversification and transformation towards a knowledge based economy with the private sector partnership (PPP) and foreign direct investment (FDI). These "smart" or "economic" cities are anticipated to fascinate people to live and work in. This exploratory study was intended to understand people's aspirations on smart city technologies that can solve urban challenges in Saudi Arabia. A total of 351 samples from the online survey, were analysed. We conclude that people in Saudi Arabia are optimistic about smart city benefits; they are also excitedly willing to contribute in smart city planning and management. We also suggest policymakers to adopt a collaborative planning mechanism based on people's wisdom to tackle more wicked urban problems and added benefits of ICT (Information \& communication technologies) and geospatial technologies.
\end{abstract}

\section{Keywords}

Smart Cities, Urban Society, Pervasive Technologies, Collaborative Planning, Saudi Arabia

\section{Introduction}

Saudi society is often less known for the global academia, especially when it 
comes to the adoption and diffusion of smart technologies; keeping it into mind this research investigation attempts to find out the aspirations of urban residents, they put forwards from the applications of "smart city" technologies.

\subsection{Smart City Discourse}

Modern cities in the past two centuries have experienced many transitions sporadic; these transitions on one hand produced numerous problems and challenges, and on the other hand compelled urban planners to offer solutions thereof. Current technological regimes are profoundly transforming principal aspects of human life by overruling physical distances in all societal activities (Castells, 1989; Harvey, 1989).

In fact, our cities are confronted with numerous environmental, social and economic catastrophes at present that appeared because of uncontrolled urban growth and flawed configurations of resource consumption; smart cities are indeed to avert catastrophes. Many smart cities are currently being built across the GCC nations, grounded in "smart" propositions and driven by global technological companies (GTCs).

The new urban development embedded with information and communication technologies (ICTs) has arisen as a vital disquisition shaping urban prosperity in future. Smart city has emerged as a solution to the complex urban challenges representing an up-to-date form of ICT driven urban paradise (Townsend, 2013).

Smart city discourse is currently drawing attention from the mass media and academic arena, yet the concept has not been meticulously defined. In fact, traces of smart city could be dug back in initial branding of cities such as wired cities, cyber cities, digital cities, creative cities, intelligent cities, informational city and ubiquitous city (Dutton et al., 1987; Graham \& Marvin, 1999; Ishida \& Isbister, 2000; Komninos, 2002; Castells, 2009; Shin, 2009) all accentuating to build a city assisted with ICTs that are aimed to bring about more efficiency in resource uses and also in ameliorating the level of various services to enhance livability for its residents. Angelidou (2014) used an operational definition of a smart city as urban settlements that are strategically stressing to make insightful efforts to take advantage of ICT setting aimed at attaining opulence, efficiency and competitiveness at various socioeconomic scales.

Smart city deploys ICTs in two ways, firstly to boost economic development and secondly to enhance urban management through broader entrenching of software applications in a city setting (Kitchin, 2014). Cities also have to trigger their resources to keep themselves competitive and attractive to create a vibrant economy progressively induced by innovations embedded with ICT and endorsed by smart citizen (Kourtit et al., 2012).

Intelligent policy responses can proliferate throughput and competitiveness of individuals, businesses \& government, and real time control and management of cities through a robust ICT platform and pervasive computing; both elements are believed to be fundamental elements of a smart city (Caragliu et al., 2009; 
Townsend, 2013).

Smart city could also be seen a city form that largely relies upon real time Big Data for the efficient management, monitoring and organised placement of ICT systems and ubiquitous computing (Townsend, 2013). Thus the idea of smart cities has been emerged in urban sciences with an assurance to create cities safer, cleaner and competent via widespread ICT applications. Smart city promoters allege that it will meticulously feel resources, actions and flows of materials in real-time, producing in "Big Data"; used to accomplish urban sustainability (IBM, 2009; Falconer \& Mitchel, 2012). Real and on time conscious choices can endure resiliency in the cities for future environmental and economic traumas.

Conversely, irrespective of many magnificent scenarios that smart cities bid, some criticisms have been levelled against them. Hollands (2008) stands among early critique of smart city technology who contends that ingraining ICT applications in all urban planning and management, errands alone cannot make over cities for good governance, equitable distribution of resources, economic prosperity and the genesis of an environmental setting with least garbage. Moreover, Goodspeed (2014) suggests at first having a better appreciation of urban glitches in a sociotechnical theoretic context of action that embraces physiognomies of terrific urban problems and the approaches to solve them; local municipal innovations and injecting ICT applications into collaborative urban planning clutches the pledge.

Actually; the idea of smart city appears to be positioned upon too intangible suppositions as some critiques claims. Greenfield (2013) argues that "smart cities" are not realistic as they are not planned and designed to function according to the needs of the people who live within them. Urban planning that is extremely based on technology might be tricky as eventually it is the people who make cities functional, not the sensors and monitors. Because of being motivated by their profits, global ICT solution provider companies are also probed for their know-how on city affairs and approaches to liveability.

Despite of all the drawbacks of smart city technology; foremost promise is that of achieving energy and resource efficiency, which is doubtlessly a precondition for urban sustainability and liveability.

\subsection{Smart City and People}

Technological advancements are commended for improving efficiency in any system operation; however, critics argue that technology alone cannot protect the planet earth from the contested limits of resource consumption that pose acute defies on the natural environment (Desai \& Riddlestone, 2002). Technologies and social institutions should be refurbished indeed in order to the closure of widening gaps between artificial designs and sustainability of natural ecosystems (Capra, 2002). While dissents are spread out along with smart cities since they setup sophisticated technologies for each and everything while in many 
cases creating cities smart is not about technology, but is about people and finding fixes for the basic human glitches (Burdett, 2014).

The critical component of a real smart city is smart people without them one cannot imagine these urban utopias (Kourtit et al., 2012; Orendain et al., 2014). Established smart cities in different parts of the world have legitimated importance of offering more interactive urban services through citizen engagements (Lee et al., 2014). As people are the pivotal recipient of "smart city" services; hence if we wish people to recognize smart city technologies, we ought to first recognize them. Many smart cities in the world has attempted to engage people in the smart cities function by ensuring unification of their needs, perceptions and aspirations; all of above their innovations.

Researchers have pointed out dearth of people-centred approach to technology in corporate stimulated smart city visions (Alawadhi \& Scholl, 2013). Coe et al. (2001) maintained smart city as a city whose community is wise enough to learn, acclimate and innovate; and its people hold talent to use technology for their own welfare. People with city administrations and entrepreneurs; are likely to embrace ICTs for the revival and strengthening of their roles in the latest knowledge economy, local job creations and improve quality of life (Anttiroiko et al., 2013).

Unfortunately, corporate promoters of smart cities are highly influential as they create a scenario where citizens are at risk of being excluded. The Amsterdam smart city program offers a fascinating combination of local innovations and experiments that engage citizens in joint projects that improve the urban environment and liveability even at street scale (ASC, 2015).

Cities like Barcelona have set a vision to make it "city of people" that aims to maximise citizen's prosperity on one hand and accelerate economic growth on the other hand. The city recognises knowledge as an impetus to upkeep production and innovation at local scale (Bakici et al., 2012). Scholars emphasised on adopting a softer approach that is to develop technological applications in order to respond and match people's aspiration, necessities, choices, multiplicity and personality (Streitz, 2011; Lind, 2012).

Consequently, people are the essential and most important component of any smart city, though they have to redefine their roles in order to adapt ICT applications in city functions aimed at improving resource efficiency, quality of life and prosperity.

\subsection{Scope of Smart Cities in Saudi Arabia}

Till 1930s Saudi Arabia owned an underprivileged economic scenario that was mainly relied on global pilgrimages to the holy cities of Makkah and Madinah (Alkhedeiri, 1998) the first-ever transition in the economy was started, followed by the discovery of petroleum oil in 1938 (Abdulaal, 1987) thereafter oil has subjugated nations forex, public revenue and national income.

Saudi Arabia is well recognised as a wealthy country; where in 2013 per capita 
gross national income was figured around 26 thousand US Dollars (World Bank, 2015); there are 2 main reasons behind higher incomes. At first it has higher petroleum oil productions while holding around 20 percent of world's petroleum oil reserves (Citibank, 2011; MOF, 2011). Secondly; it has an enormous stock of mineral deposits as well as natural gas (Shawly, 2008) which is echoed in the form of rapid urbanization rates; only 10 percent of the urban population in 1950 was living in cities that reached 75 percent by the year 1985 while the figure of urban dwellers is expected to reach 83.2 percent by 2015 (Al-Ankary \& El-Bushra, 1989; UN-Habitat, 2012).

Oil exploration in the kingdom on one hand has offered strong backing to its economy reflected in the individual's income and wealth, on the other hand it has altered way of living in cities by making it more physically inactive. Moreover cheap fuel, low car prices and limited availability of public transportation has increased private car ownerships. Moreover, low availability of pedestrian pathways and lack of green spaces has dominated big Saudi cities. All above factors cumulatively has enlarged risk of obesity, high blood pressures, hypertension, stress and diabetes (Ng et al., 2011; UN-Habitat, 2012).

Core development strategies in $9^{\text {th }}$ Saudi Arabia's National Development Plan (MoEP, 2009) were identified as improving general conditions pertaining to the quality of life (livability), greater prominence for environmental protection and resource conservation, creating higher job opportunities for the local young population (local labor market is predominantly depends upon expatriate workers at present), crafting balanced regional development; engaging private sectors for development partnerships (PPP), economic diversification with a profound presence at global competitive markets and transformation towards a knowledge-based economy from an oil-based economy.

Saudi cities are confronting with severe challenges mainly because of scared natural resources (i.e. water, vegetation and bio-diversity) unsustainable resource consumption, rapid urbanization and population growth and higher dependence on fossil fuels for each and every aspect of day-to-day life. Concurrently; experts warned on uncontrolled domestic fuel consumptions that can lead higher risk of catastrophe to sustainability (environmental, economic and social) in the future (Lahn \& Stevens, 2011). As a solution, economic, holding capabilities of smart cities, are anticipated to sort out series of mounting urban sustainability challenges in Saudi Arabia. As the senior director of EMMAR (the private company which is developing King Abduallah Economic city-KAEC) articulates that KAEC clutches competence of a smart city by rendering value added system for real time assistance to the foreign investors. This ICT based system incorporates all traits of living and businesses (EMMAR, 2008).

In fact, plan to establish 6 economic cities (Figure 1 and Table 1) portrays the country's post oil future (Moser et al., 2015) and attempts to establish a new era of urban planning to plan cities from scratch.

Proposed economic cities will be planned on 6 basic design principles (Figure 
2) inclusive of ICT based trendy hard and soft infrastructure, globally competitive core function (i.e. education, real estate, healthcare, industries, agribusiness and so on); potentials of partnership with private sector and enabling business

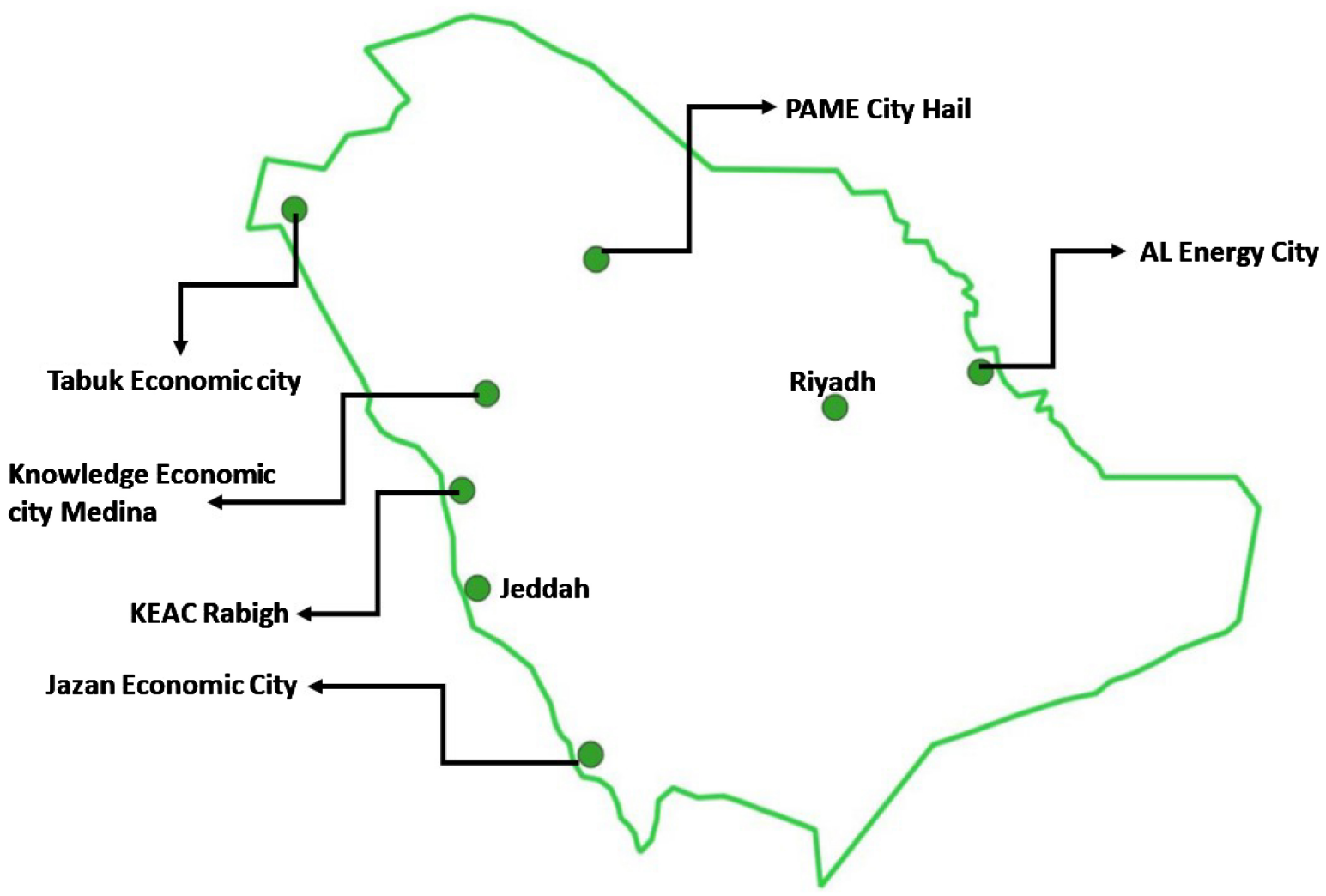

Figure 1. Location of economic cities in the Kingdom of Saudi Arabia (Map not to scale).

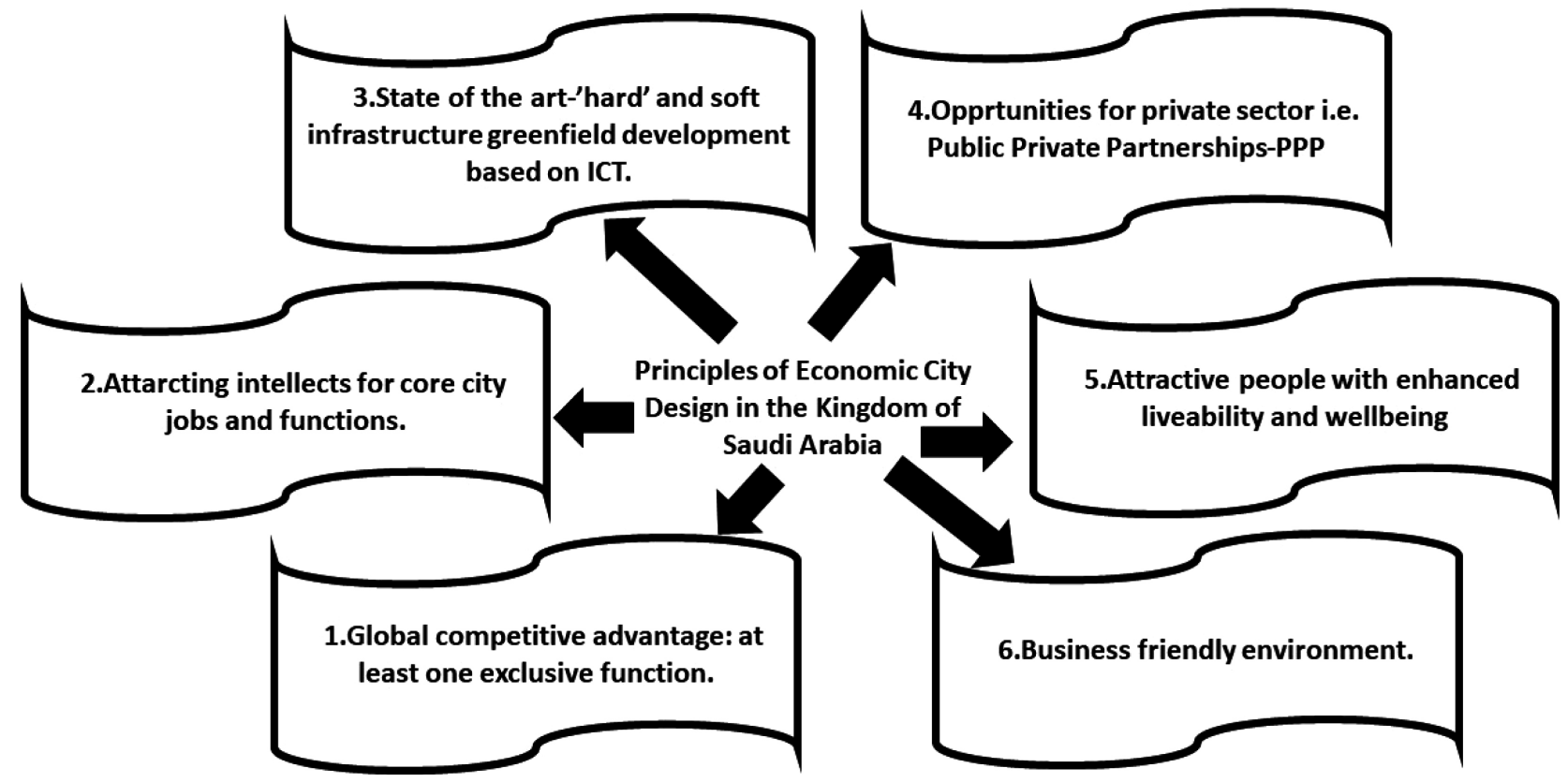

Figure 2. Basic design principles in the design of economic cities of the Kingdom of Saudi Arabia. 
Table 1. Proposed economic cities in Saudi Arabia.

\begin{tabular}{|c|c|c|c|c|}
\hline City & $\begin{array}{l}\text { Estimated } \\
\text { Investment } \\
\text { (In Billion } \\
\text { USD) }\end{array}$ & Region & Location & Core functions \\
\hline $\begin{array}{l}\text { 1) King Abdullah } \\
\text { Economic city-KAEC }\end{array}$ & 86.0 & West & $\begin{array}{l}\text { Rabigh } \\
\text { (near } \\
\text { Jeddah) }\end{array}$ & $\begin{array}{c}\text { Economic diversification, } \\
\text { attracting foreign } \\
\text { investment, to be key } \\
\text { player global trade, } \\
\text { industry and commerce. }\end{array}$ \\
\hline $\begin{array}{l}\text { 2) Prince Abdulaziz } \\
\text { Bin Mousaed } \\
\text { Economic } \\
\text { City-PAMEC }\end{array}$ & 8.0 & North & Hail & $\begin{array}{c}\text { Agribusiness, } \\
\text { construction } \\
\text { materials and } \\
\text { logistics; secondary } \\
\text { functions real estate, } \\
\text { tourism and other light } \\
\text { industries. }\end{array}$ \\
\hline $\begin{array}{l}\text { 3) Knowledge } \\
\text { Economic } \\
\text { City-KEC }\end{array}$ & 6.7 & Mid-West & Medina & $\begin{array}{l}\text { Establishing knowledge } \\
\text { based industries, } \\
\text { education and media } \\
\text { hub, secondary functions } \\
\text { includes: healthcare, } \\
\text { tourism and real estate. }\end{array}$ \\
\hline 4) Jazan City & 26.7 & South & Jazan & $\begin{array}{l}\text { Heavy industries and } \\
\text { processing } \\
\text { (value adding) industries. }\end{array}$ \\
\hline 5) ALEC-Energy City & & North-East & Alahassa & $\begin{array}{c}\text { Clean energy } \\
\text { development and } \\
\text { research; light industries. }\end{array}$ \\
\hline 6) Tabouk City & & North-West & Tabouk & $\begin{array}{l}\text { Heavy industries and } \\
\text { processing industries. }\end{array}$ \\
\hline
\end{tabular}

friendly environment and all these are envisioned to fascinate professionals and other common residents to work and live in livable ambiances. KAEC is the first economic city supposed to be completed in the year 2020; around 25 percent development in the city has been done; the idea of KAEC is discussed further.

\subsection{King Abdullah Economic City (KAEC): A Visionary Smart City}

King Abdullah Economic City is situated on the coast of the Red Sea, about 100 $\mathrm{km}$ north of Jeddah, the second largest city of the kingdom that serves as commercial capital and gateway to the holy cities. The city comprises a development area of 173 square kilometres with approximately 86 billion $\$$ anticipated investment. In the bouquet of six economic cities KAEC is the most important and aspiring city that aims to make Saudi Arabia a topmost investment hub.

Though, the success or failure of KAEC is quite far and hard to predict by now, though it is viewed as a groundbreaking model for post oil economic planning (Moser, 2014). KAEC manifesto assures to generate one million new job 
opportunities for Saudi youth and act as an investment model for economic and social welfare of Saudis. An initial investment of 100 Billion $\$$ is anticipated in the development of KAEC. The Master plan of KAEC encompasses six separate zones: 1) industrial, 2) educational 3) residential 4) recreational 5) business and 6) seaport. Water supply in the city will be ensured by two water desalination plants while two power plants will be constructed at the northern tip of the city. The high speed Haramin Railway will link KAEC with Jeddah and the holy city of Makkah and Medina. The city will offer a connected compact and coordinated neighborhood with ease of walkability, bicycling and public transport amenities. The city will also offer a variety of housing solutions from high end villas to low end apartments with an energetic and relaxed lifestyle (KAEC, 2014).

\section{Research Aim}

A corporate study established that previous studies have somewhat overlooked citizens' aspirations in the planning of Saudi Arabian cities which forms a starting point for informed and impressive business decisions (Alcatel-Lucen, 2013); study findings motivated us to carry out this research.

The main aim of this research investigation is; to explore people's aspirations from future smart cities in Saudi Arabia and how they reposition their mindset to contribute for a collaborative urban planning and management.

We have attempted to examine following research questions:

1) What is people's understanding of smart cities in the local urban context?

2) How the smart city technology will impact various urban essences?

3) Up to what extent, and scale people are willing to contribute for smart city planning and management?

4) Themes, models and types of information and data that people want to share for real time decision making in smart city?

\section{Materials and Methods}

\subsection{Materials}

We used both primary and secondary data for the research investigation. On first hand, for gathering primary data; an online survey was carried out during the 1st and 2nd week of January 2015 for primary data collection. We used semi-structured Questionnaire for the research investigation on the Google Form platform. It comprises 14 questions out of which 1 open question was included to know their top 3 preferences about city fixes. Reliability of the questionnaire was maintained by keeping it standardized. The questionnaire was circulated among the faculty members and students of King Abdulaziz University, Jeddah (KSA). Moreover, the authors circulated the links of questionnaire over their social media networks: LinkedIn, twitter, Facebook and WhatsApp.

Besides primary data in the first place, the secondary data were collected 
through a literature review of the existing government documents, industry reports and media. We utilized mostly the materials that were available online.

\subsection{Procedures}

Primarily a 5-point Likert scale-strongly disagree to strongly agree (scores from 1 to 5) was used to explore people's understanding on smart city in Saudi Arabia. Perceptions were analysed on the various critical issues such sustainability of technology driven urban development solutions, organic growth of cities after embracing smart city technologies, impact of smart city technologies on environmental conditions, and its connections to urban liveability (Table 2). Questions were also asked about people's preferences on the elements to be integrated in the smart city framework; preferred format of smart city, types and modes of data and information citizens wants to supplement in smart city setup. Obtained primary data was analysed using descriptive statistics.

Furthermore, the Questionnaire contained open query to capture any missing component that ensures the success of a smart city from a citizen's perspective.

\subsection{Sample Respondents}

A sample from urban residents of Saudi Arabia $(n=351)$ aged 18 to 66 years $(M=$ $36.29, \mathrm{SD}=11.65$ ) years was procured through online survey tool for data gathering. A brief Socio-economic profile of samples is presented in Table 3.

\section{Results and Discussions}

Smart city movement is gaining traction from the urbanists worldwide who also admits that smartness in a city emanates from "smart people" that forms core for

Table 2. What people apprehends on smart city technology in Saudi Arabia.

\begin{tabular}{|c|c|c|c|c|c|}
\hline & Issue & Question & $\mathrm{n}$ & Mean & SD \\
\hline Que.1 & Viability & $\begin{array}{l}\text { Is technology driven urban } \\
\text { planning and management is a } \\
\text { panacea to ensure sustainable } \\
\text { development? }\end{array}$ & 351 & 4.01 & 0.88 \\
\hline Que.2 & Individuality & $\begin{array}{l}\text { Will the city be able to grow } \\
\text { naturally after embracing } \\
\text { smart city which is quite } \\
\text { simpler but attractive idea? }\end{array}$ & 351 & 4.10 & 0.85 \\
\hline Que.3 & $\begin{array}{c}\text { Environmental } \\
\text { Quality }\end{array}$ & $\begin{array}{l}\text { Will smart city technology be } \\
\text { helpful to enhance } \\
\text { environmental quality and } \\
\text { curtail pollution such as air } \\
\text { pollution, water pollution, soil } \\
\text { pollution, noise pollution etc. }\end{array}$ & 351 & 4.11 & 0.90 \\
\hline Que.4 & Livability & $\begin{array}{l}\text { Will smart city technology } \\
\text { improve quality of life and } \\
\text { well-being in general? }\end{array}$ & 351 & 4.53 & 0.78 \\
\hline
\end{tabular}


Table 3. Socio-economic profile of the sample.

\begin{tabular}{|c|c|c|c|}
\hline & & Number $(n=351)$ & Percentage \\
\hline \multicolumn{4}{|l|}{ Gender } \\
\hline & Male & 230 & 65.5 \\
\hline & Female & 121 & 34.5 \\
\hline \multicolumn{4}{|l|}{ Age } \\
\hline & Less than 20 & 10 & 2.8 \\
\hline & 20 to 40 & 231 & 65.8 \\
\hline & 40 to 60 & 101 & 28.8 \\
\hline & Above 60 & 9 & 2.6 \\
\hline \multicolumn{4}{|l|}{ Education } \\
\hline & General graduate & 109 & 31.1 \\
\hline & Professional graduate & 70 & 19.9 \\
\hline & Masters & 31 & 8.8 \\
\hline & Doctorate & 16 & 4.6 \\
\hline & Others & 125 & 35.6 \\
\hline \multicolumn{4}{|l|}{ Profession } \\
\hline & Student & 129 & 36.8 \\
\hline & Researcher & 14 & 4.0 \\
\hline & Educator & 22 & 6.3 \\
\hline & Engineer & 23 & 6.6 \\
\hline & Consultants & 8 & 2.3 \\
\hline & Others & 155 & 44.2 \\
\hline
\end{tabular}

smart economy, smart mobility, smart living, smart governance and smart environment. Smart people mean the presence of citizen that is determined, sovereign and conscious for a prosperous urban living (Tok et al., 2014).

Amsterdam Smart City is an outstanding example of citizen participation initiatives that recognizes people's aspirations for a real smart city. A resident of this city expresses: "Smart City means to me is it becoming a city that can quickly and continuously respond to changing circumstances from within its current form (ASC, 2015)".

The research investigation shows that people in Saudi Arabia have a sound understanding of smart city technologies. Sample respondents agreed (mean 4.01 ) on the point of viability of smart city technologies with an insignificant variability in their perceptions (SD 0.88). Similarly respondents were "agree" that smart city technology can allow cities to grow naturally (mean 4.10 and SD 0.85). Additionally respondents strongly expressed that smart city technologies will be helpful in the improvement of urban environmental quality while minimising pollutions (Mean 4.11 and SD 0.90); responses tends towards a higher agreement for the role of smart cities technologies in improving livability and wellbeing (Mean 4.53 and SD 0.78). 
Respondents were in a little dilemma if the smart city technology can really impact various urban elements in a positive manner (Table 4). Although their responses were tending, to the above "neutral" (score 3), below from being "agree" (score 4). The same trend was witnessed for all urban essences such as environment and bio-diversity (Mean 3.6), energy efficiency (Mean 3.8), public transportation (Mean 3.9), smart living (Mean 3.8), smart building (Mean 3.7), being an age and gender friendly city (Mean 3.9), urban health (Mean 3.8), urban governance (Mean 3.8) and to be walkable and bike friendly city (Mean 3.9).

Participatory urban planning has caught attention of professionals and policy makers, especially in developing countries during the last few decades to better accommodate the needs and aspirations of local urban residents (Diana, 2010; Michael, 2010).

Professionals suggested various approaches, platforms and applications based on ICT and geospatial technologies (Cardone et al., 2013; Roche, 2014; Unsworth et al., 2014). Participatory urban planning has been moved now one step ahead in form of collaborative urban planning (Maginn, 2007; Hollander, 2011) where the emphasis is upon the co-creation of the urban plan for which smart city technology should offer ample opportunities.

We examined people's willingness to participate in the planning and management of smart cities (Table 5) and found that people are eager to be engaged with other citizen and local officials (Mean 4.2 and SD 0.85), willing to participate in the execution (Mean 4.0 and SD 0.92), volunteer to contribute in decision making (Mean 4.2 and SD 0.75) and keen to be consulted (Mean 4.1 and SD 0.82 ) and informed (Mean 4.2 and SD 0.85).

To crosscheck we asked their perception on "I don't want to participate" and found respondents "highly disagreed" (Mean 1.5 and SD 0.58).

Thus; Saudi people are enthusiastic for their participation in smart city planning and management.

Critiques blame smart cities such as New Songdo in South Korea and Masdar in the UAE for not delivering milieus where individuals really want to work and

Table 4. Potential impact of smart city technologies on various urban essences.

\begin{tabular}{cccc}
\hline & $\mathbf{n}$ & Mean & SD \\
\hline 1) environment and bio-diversity & 329 & 3.6 & 1.4 \\
2) energy efficiency & 351 & 3.8 & 1.3 \\
3) public transportation & 340 & 3.9 & 1.3 \\
4) smart living & 351 & 3.8 & 1.2 \\
5) smart building & 351 & 3.7 & 1.4 \\
6) being an age and gender friendly & 351 & 3.9 & 1.1 \\
$\quad$ city & 351 & 3.8 & 1.3 \\
7) urban health & 351 & 3.8 & 1.1 \\
8) urban governance & 351 & 3.9 & 1.1 \\
\hline
\end{tabular}


Table 5. Willingness to participate in smart city planning and management.

\begin{tabular}{cccc}
\hline Responses on willingness & $\mathrm{n}$ & Mean & SD \\
\hline $\begin{array}{c}\text { I want to be engaged with } \\
\text { other citizen and local officials }\end{array}$ & 351 & 4.2 & 0.85 \\
$\begin{array}{c}\text { I am willing to participate in the } \\
\text { execution of Smart cities }\end{array}$ & 351 & 4 & 0.92 \\
I am volunteer to contribute in $\quad$ decision making & 321 & 4.2 & 0.75 \\
$\quad$ I want to be consulted & 351 & 4.1 & 0.82 \\
I want to be informed & 351 & 4.2 & 0.85 \\
I don't want to participate & 351 & 1.5 & 0.58 \\
\hline
\end{tabular}

live in; the reason behind it was disregarded social dynamics while overemphasis on engineering and technological networks; the solution is to deliver goods and services that people really demand for adding real values to their own life (Saint, 2014).

Majority of respondents stressed to make a city smart with efficient and reliable mass rapid transport system (66 percent) and a city with ample green areas and virtuous environment quality (66 percent) followed by improved energy efficiency ( 57 percent), walkable $\&$ bike friendly city (31 percent) knowledge based economy (29 percent), valuing innovation and competitiveness (29 percent), city embedded with sensors and networks ( 26 percent), age friendly city ( 23 percent) and others ( 3 percent). Respondents have shown more humane facets to be preferred (Table 6) in smart city ingredients.

Regarding the format of smart cities respondents stressed to develop a modified local model (55 percent) based on the learning from other international models; some respondents favoured developing entirely unique local format (23 percent) while only few (55 percent) suggested copying Eurocentric models (Table 7).

We found that respondents are mostly enthusiastic to share their knowledge and skills (Table 8) to report events like road accidents and traffic conditions (74 percent) urban designing and planning (71 percent) and sharing local knowledge. Whilst; minority of respondents were attentive to make grievances/complaints (29 percent) and contributing innovative ideas (21 percent).

Table 9 shows typology of knowledge respondents willing to share for smart city decisions. Geographical information plays crucial role in taking real time decisions in sustainable urban planning and management (Jensen et al., 2014). Majority of respondents (71 percent) are willing to share geographical or spatial information and photographs (71 percent) followed by textual data (60 percent), video (51 percent) and voice (51 percent).

Table 10 indicates mode of information sharing whereas internet/web ( 80 percent) and smartphones (74 percent) were the most prevalent; only a small number of respondents were in favour of using manual methods (20 percent) 
Table 6. Preferences on smart city elements.

\begin{tabular}{cc}
\hline Smart city element (maximum of 3 responses) & Responses in \% \\
\hline ICT based city embedded with sensors and networks & 26 \\
City with ample green areas and virtuous environment quality & 66 \\
City with improved energy efficiency & 57 \\
City good for old people and children. & 23 \\
Walkable \& bike friendly city & 66 \\
City with valued innovation and competitiveness & 31 \\
A city of knowledge based economy & 23 \\
Others & 29 \\
\hline
\end{tabular}

Table 7. Format of smart city.

\begin{tabular}{cc}
\hline Smart city format & Responses in \% \\
\hline Copying from Eurocentric design models. & 17 \\
Developing entirely unique local format of smart city & 23 \\
Modify models from other countries best fit to local urban situations & 54 \\
I don't know & 0 \\
Others & 6 \\
$\mathrm{n}=351$ & \\
\hline
\end{tabular}

Table 8. Knowledge sharing for decision making in the smart city.

\begin{tabular}{cc}
\hline Information & Responses in \% \\
\hline $\begin{array}{c}\text { Reporting events like road accidents/traffic congestion/environmental } \\
\text { pollution/urban flooding/fire } \\
\text { Contributing innovative ideas } \\
\text { Making complaints/grievances }\end{array}$ & 74 \\
Participation in urban plans/designs & 21 \\
Sharing local knowledge & 29 \\
Others & 71 \\
& 51 \\
\hline
\end{tabular}

Table 9. Types of information people willing to share.

\begin{tabular}{cc}
\hline Information type & Responses in \% \\
\hline Voice/audio & 51 \\
Photographs & 71 \\
Text & 60 \\
Video & 51 \\
Geographical/spatial information & 71 \\
Others & 9 \\
\hline
\end{tabular}


Table 10. Mode of information sharing.

\begin{tabular}{cc}
\hline Mode & Responses in \% \\
\hline Manually by hand & 23 \\
Internet/web & 80 \\
Smartphones & 74 \\
Voice calling & 20 \\
Others & 9 \\
\hline
\end{tabular}

and voice calling (20 percent).

In addition to above we found people wishes to see more upgradation in urban traffic management, ensuring standards for the park and appointing gardeners to safeguard, raising public awareness on urban sustainability issues, organising invention and innovation fairs, improving health services, protecting consumer's rights, improving grievance handling mechanism, reducing overreliance upon expatriates and working in a wholehearted manner.

Results of this exploratory research investigation prompts for further research on the issue at a more micro scale to make Saudi cities smart.

Less participation of the female respondents in online survey was a major limitation in the research investigation while the perception of those who do not have access to digital gadgets was also omitted. However, these limitations are not significant as the nature of the study was exploratory.

\section{Conclusion}

Although smart cities are actively driven by international competitive market forces and advanced technological solutions, planners and policymakers must have room to amalgamate local physiognomies with the needs and preferences of people. We argue that, future smart cities are not just about deploying technologies for efficient resource management or increasing accessibility of public services and utilities. Actually, on one hand, futuristic smart cities should act in a more collaborative manner for policy and decision-making, and on the other hand, populace in these smart cities should learn to share resources, such as energy, data and cars to ensure sustainability. We foresee smart city technologies to promote wise resource use in Saudi Arabian cities while valuing people over technologies.

\section{References}

Abdulaal, W. A. (1987). Land Subdivision and the Development Process in Medina, Analysis of the Landowner's Role. Unpublished Ph.D. Thesis, Cardiff: University of Wales.

Al-Ankary, K. M., \& El-Bushra, El-S. (1989) Urban and Rural Profiles in Saudi Arabia. Berlin: G. Borntraeger.

Alawadhi, S., Scholl, H. J. J. (2013). Aspirations and Realizations: The Smart City of Seattle. In: The 46th Hawaii International Conference on System Sciences, IEEE Proceed- 
ings (pp. 1695-1703). Maui, HI: Wailea. https://doi.org/10.1109/HICSS.2013.102

Alcatel-Lucen. (2013). The Stakeholders, How Are Roles Evolving to Enable Smart Development?

http://www.tmcnet.com/tmc/whitepapers/documents/whitepapers/2013/8215-alcatel-1 ucent-voice-smart-city-citizens-saudi-presentation.pdf

Alkhedeiri, A. (1998). The Role of Secondary Cities in the National Development Process of Saudi Arabia. Unpublished Ph.D. Thesis, London: University College.

Angelidou, M. (2014). Smart City Policies: A Spatial Approach. Cities, 41, S3-S11. https://doi.org/10.1016/j.cities.2014.06.007

Anttiroiko, A.-V., Valkama, P., \& Bailey, S. (2013). Smart Cities in the New Service Economy: Building Platforms for Smart Services. Journal of AI and SOCIETY, 28, 1-12.

ASC Amsterdam Smart City (2015). http://amsterdamsmartcity.com

Bakici, T., Almirall, E., \& Wareham, J. (2012). A Smart City Initiative: The Case Barcelona. Journal of the Knowledge Economy. Journal of the Knowledge Economy, 4, 135-148.

Burdett, R. (2014). Urban Planner: “Smart Cities” Are Problematic. http://www.dw.de/urban-planner-smart-cities-are-problematic/a-18057258

Capra, F. (2002). The Hidden Connections - A Science for Sustainable Living. London: Flamingo.

Caragliu, A., Del Bo, C., \& Nijkamp, P. (2009). Smart Cities in Europe. Series Research Memoranda 0048. Amsterdam: VU University Amsterdam, Faculty of Economics, Business Administration and Business Administration and Econometrics.

Cardone, G., Foschini, L., Bellavista, P., \& Corradi, A. (2013). Fostering Participation in Smart Cities: A Geo-Social Crowd sensing Platform. IEEE Communications Magazine, June 2013.

Castells, M. (1989). The Informational City: Information Technology, Economic Restructuring, and the Urban-Regional Process. New York, NY: Blackwell.

Castells, M. (2009). Communication Power. Oxford: Oxford University Press.

Citibank (2011). Saudi Arabia to Have 6th Highest per Capita GDP by 2050: Report. http://articles.economictimes.indiatimes.com/2011-03-08/news/28668672_1_gdp-capit al-formation-saudi-arabia

Coe, A., Paquet, G., \& Roy, J. (2001). E-Governance and Smart Communities: A Social Learning Challenge. Journal on Social Science Computer Review, 19, 80-93. https://doi.org/10.1177/089443930101900107

Desai, P., \& Riddlestone, S. (2002). Bioregional Solutions for Living on One Planet. Foxhole: Green Books.

Diana, M. C. (2010). Urban and Regional Planning and Development Series: Discourse Dynamics in Participatory Planning. Farnham: Ashgate Publishing Group.

Dutton, W. H., Blumler, J. G., \& Kraemer, K. L. (1987). Wired Cities: Shaping Future Communication. New York, NY: Macmillan.

EMMAR (2008). King Abdullah Economic City: A Smart Destination for Long-Term Growth. Sponsored Profile, Saudi Arabia Report 2008, Finance Asia.

Falconer, G., \& Mitchell, S. (2012). Smart City Framework A Systematic Process for Enabling Smart + Connected Communities, CISCO.

http://www.cisco.com/web/about/ac79/docs/ps/motm/Smart-City-Framework.pdf

Goodspeed, R. (2014). Smart Cities: Moving beyond Urban Cybernetics to Tackle Wicked 
Problems. Cambridge Journal of Regions, Economy and Society, 8, 79-92.

Graham, S., \& Marvin, S. (1999). Planning Cyber Cities: Integrating Telecommunications into Urban Planning. Town Planning Review, 70, 89-114.

https://doi.org/10.3828/tpr.70.1.w34454x3475g2858

Greenfield, A. (2013). Against the Smart City. New York, NY: Do Publications.

Harvey, D. (1989). The Condition of Post Modernity: An Enquiry into the Origins of Cultural Change. Cambridge, MA: Blackwell.

Hollander, J. B. (2011). Approaching an Ideal: Using Technology to Apply Collaborative Rationality to Urban Planning Processes. Planning Practice \& Research, 26, 587-596. https://doi.org/10.1080/02697459.2011.627001

Hollands, R. (2008). Will the Real Smart City Please Stand Up? Creative, Progressive or Just Entrepreneurial? City: Analysis of Urban Trends, Culture, Theory, Policy, Action, 12, 303-320. https://doi.org/10.1080/13604810802479126

IBM (2009). A Vision of Smarter Cities. http://www03.ibm.com/press/attachments/IBV_Smarter_Cities_-_Final.pdf

Ishida, T., \& Isbister, K. (2000). Digital Cities: Technologies, Experiences, and Future Perspectives. LNCS: Springer. https://doi.org/10.1007/3-540-46422-0

Jensen, M., Gutierrez, J., \& Pedersen, J. (2014). Location Intelligence Application in Digital Data Activity Dimensioning in Smart Cities. Procedia Computer Science, 36, 418-424. https://doi.org/10.1016/j.procs.2014.09.015

KAEC (2014). King Abdullah Economic City Official Website. http://www.kingabdullahcity.com/en/Home/index.html

Kitchin, R. (2014). The Real-Time City? Big Data and Smart Urbanism. GeoJournal, 79, 1-14. https://doi.org/10.1007/s10708-013-9516-8

Komninos, N. (2002). Intelligent Cities: Innovation. Routledge: Knowledge Systems and Digital Spaces.

Kourtit, K., Nijkamp, P., \& Arribas-Bel, D. (2012). Smart Cities Perspective-A Comparative European Study by Means of Self-Organizing Maps. Innovation, 25, 229-246. https://doi.org/10.1080/13511610.2012.660330

Lahn, G., \& Stevens, P. (2011). Burning Oil to Keep Cool: The Hidden Energy Crisis in Saudi Arabia, Chatham House. London: The Royal Institute of International Affairs. http://www.chathamhouse.org/sites/files/chathamhouse/public/Research/Energy,\%20E nvironment\%20and\%20Development/1211pr_lahn_stevens.pdf

Lee, J. H., Hancock, M. G., \& Hu, M. (2014). Towards an Effective Framework for Building Smart Cities: Lessons from Seoul and San Francisco. Technological Forecasting \& Social Change, 89, 80-99. https://doi.org/10.1016/j.techfore.2013.08.033

Lind, D. (2012). Information and Communications Technologies Creating Livable, Equitable, Sustainable Cities. In L. Starke (Ed.), State of the World 2012: Moving toward Sustainable Prosperity. Island Press. https://doi.org/10.5822/978-1-61091-045-3_5

Maginn, P. J. (2007). Towards More Effective Community Participation in Urban Regeneration: The Potential of Collaborative Planning and Applied Ethnography. Qualitative Research, 7, 25-43. https://doi.org/10.1177/1468794106068020

Michael, M. (2010). Participatory Spatial Planning: Learning from Rural Ireland. Farnham: Ashgate Publishing Group.

MoEP Ministry of Economy and Planning (2009). Brief Report on the Ninth Development Plan. Kingdom of Saudi Arabia, 24. 
MOF Ministry of Finance (2011). The Annual Budget of Saudi Arabia, Riyadh.

Moser, S. (2014). New Cities: Opportunities, Visions and Challenges-City Quest KAEC Forum 2013: Summary and Analysis Report. Paris: New Cities Foundation. http://www.newcitiesfoundation.org/wp-content/uploads/2014/05/PDF-CityquestKAE CForum-Report-Sarah-Moser.pdf

Moser, S., Swain, M., \& Alkhabbaz, M. H. (2015). King Abdullah Economic City: Engineering Saudi Arabia's Post-Oil Future. Cities, 45, 71-80. https://doi.org/10.1016/j.cities.2015.03.001

Ng, S. W., Zaghloul, S., Ali, H. I., Harrison, G., \& Popkin, B. M. (2011). The Prevalence and Trends of Overweight, Obesity and Nutrition-Related Non-Communicable Diseases in the Arabian Gulf States. Obesity Reviews, 12, 1-13.

https://doi.org/10.1111/j.1467-789X.2010.00750.x

Orendain De Obeso, A., LopezNeri, E., Dominquez, J., \& Gutierrez Garcia, J. O. (2014). Smart People: Enhancing CCD Citizens' Engagement through Data Utilization. IEEECCD Smart Cities White Paper.

Roche, S. (2014). Geographic Information Science I: Why Does a Smart City Need to Be Spatially Enabled? Progress in Human Geography, 38, 703-711. https://doi.org/10.1177/0309132513517365

Saint, A. (2014). The Rise and Rise of the Smart City. Engineering \& Technology October 2014 Issue. http://www.EandTmagazine.com

Shawly, H. H. (2008). Urban Water: Integrated Resource Planning to Meet Future Demand in Jeddah-Saudi Arabia. Unpublished PhD Thesis, University of Stuttgart.

Shin, D. H. (2009). Ubiquitous City: Urban Technologies, Urban Infrastructure and Urban Informatics. Journal of Information Science, 35, 515. https://doi.org/10.1177/0165551509100832

Streitz, N. (2011). Smart Cities, Ambient Intelligence and Universal Access. In C. Stephanidis (Ed.), Universal Access in HCI, Part III, HCII 2011, LNCS 6767. Berlin, Heidelberg: Springer-Verlag. https://doi.org/10.1007/978-3-642-21666-4_47

Tok, E., Al Mohammad, F., \& Al Merekhi, M. (2014). Crafting Smart Cities in the Gulf Region. European Scientific Journal, 2.

Townsend, A. (2013). Smart Cities: Big Data, Civic Hackers, and the Quest for a New Utopia. New York, NY: W.W. Norton and Company.

UN-Habitat (2012). The State of Arab Cities 2012: Challenges of Urban Transition. United Nations Human Settlements Programme, Nairobi-Kenya: UN-Habitat.

Unsworth, K., Forte, A., \& Dilworth, R. (2014). Urban Informatics: The Role of Citizen Participation in Policy Making. Journal of Urban Technology, 21, 1-5.

https://doi.org/10.1080/10630732.2014.971527

World Bank (2015). Country Data Saudi Arabia. https://data.worldbank.org/country/saudi-arabia 